\title{
A Model of Continuous Improvement Programme Management
}

Michael Butler and Marek Szwejczewski and Michael Sweeney

${ }^{a}$ Work \& Organisational Psychology Group, Aston University, Birmingham, UK;

${ }^{b}$ Cranfield School of Management, Cranfield University, Bedford, UK; ${ }^{c}$ Cranfield

School of Management, Cranfield University, Bedford, UK

Journal: Production Planning \& Control

Final Accepted Version 2018 


\title{
A Model of Continuous Improvement Programme Management
}

\section{Michael Butler and Marek Szwejczewski and Michael Sweeney}

${ }^{a}$ Work \& Organisational Psychology Group, Aston University, Birmingham, UK; ${ }^{b}$ Cranfield School of Management, Cranfield University, Bedford, UK; ${ }^{c}$ Cranfield School of Management, Cranfield University, Bedford, UK

\author{
Dr. Michael JR Butler* \\ Aston Business School \\ Aston University \\ Aston Triangle \\ BIRMINGHAM \\ B4 7ET \\ $\mathrm{UK}$ \\ Telephone: 07919926362 \\ E-mail:m.j.r.butler@aston.ac.uk \\ Professor Marek Szwejczewski (Corresponding Author) \\ Cranfield School of Management \\ Cranfield University \\ Cranfield \\ BEDFORD \\ MK43 0AL \\ UK \\ Telephone: 01234754421 \\ E-mail: m.g.szwejczewski@cranfield.ac.uk

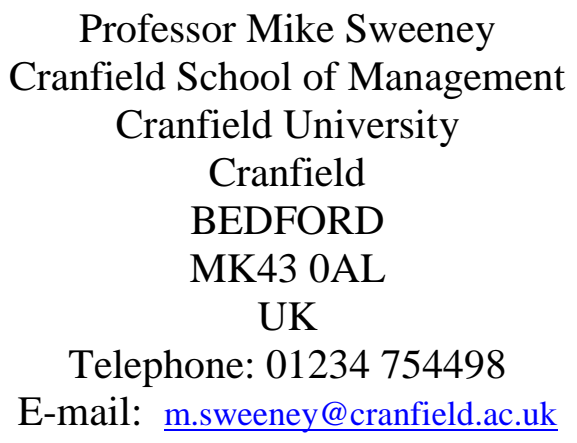




\section{A Model of Continuous Improvement Programme Management}

The aim of this study is to identify key management decisions that enable the sustainment of a continuous improvement (CI) initiative. To accomplish this aim, we examine the procedures and practices used by two manufacturing companies for the management of their CI initiatives; one that is successfully sustaining the effectiveness of its CI initiative and another failing to do the same. This research makes two contributions to the conceptual understanding of CI programme management. First, we identify five CI programme management factors that enable the sustainment of a CI initiative. Second, the five factors are incorporated into a new CI programme management model. The model details a 'bottom-up' procedure for the generation of manufacturing performance improvement ideas and the management of their implementation.

Keywords: continuous improvement; manufacturing process; people empowerment; process mapping

\section{$1 \quad$ Introduction}

Zolo and Winter $(2002,340)$ define continuous improvement (CI) as 'a learned and stable pattern of collective activity through which the organisation systematically generates and modifies its operating routines in pursuit of improved effectiveness'. Although CI is widely practised, organisations have experienced difficulty with sustaining the momentum of their activities (Mauri, Garetti, and Gandelli 2010). This has been attributed to a poor understanding of the process of change management within CI initiatives (Rapp and Eklund 2002). A commonly adopted approach to CI has been to implement ad hoc process improvement projects by simply applying established CI tools and techniques. Implementing such an approach is most likely to fail if the infrastructure needed to sustain a momentum of improvement has not been put in place (Anand et al. 2009; Galeazzo, Furlan, and Vinelli 2017). Previously reported failure to do this may be attributable to the abstract nature of published guidelines on CI 
capability development (Garcia-Sabater, Marin-Garcia, and Perello-Marin 2012) and the lack of detail on the elements of a process for CI programme management. A better understanding of such a process could improve its practice, and, therefore, our research question was: what are the key management decisions that enable the sustained continuous improvement of operational performance?

To answer the question, we adopted the $\mathrm{CI}$ infrastructure framework proposed by Anand et al. (2009) that depicts the key management decision categories that are 'the essence of CI infrastructure and affect the sustainability of the initiative' (Anand et al., 2009). These broad categories of management decisions are classified as purpose, process and people. Purpose management decisions cover the business and manufacturing performance improvement goals set for a CI initiative. Process management decisions represent the organisational procedures established for the submission of CI ideas for performance improvement and for the implementation of approved change proposals. People management decisions are those that determine company policies for the training and motivation of employees to participate in a CI initiative. Using these three broad categories of management decisions to structure our enquiry, we examined the CI initiative implementations of two manufacturing businesses; one achieving the sustained CI of its production performance and another failing in its attempt to do the same. The investigation identified both the similarities and differences in the processes they employed for CI programme management.

The unit of analysis for the research was the manufacturing operations of a factory because the practices instituted to manage a CI programme are both determined and executed at this level. Two contributions are made to the knowledge on the management of CI programmes. First, we propose five CI programme management factors that have not been considered in detail previously but which enable CI 
programme sustainment. Second, these findings enable the development of a new 'bottom-up' CI programme management model.

Next, we review previous research findings on the three broad categories of decisions that are the essence of $\mathrm{CI}$ infrastructure and that affect $\mathrm{CI}$ initiative sustainment. In Section 3, our case study methodology is detailed. In Section 4, the results are summarised. In the final section, we conclude by critically discussing the theoretical contributions, and identifying the limitations of the research design, suggesting future research.

\section{Literature review}

\subsection{The purpose of developing a CI capability}

Continuous improvement is considered to be a systematic procedure for repeatedly seeking and implementing new and improved methods of working (Bessant, Caffyn and Gallagher 2001; Wu and Chen 20060. As Prahalad and Hamel (1990, 81) commented, 'the real sources of advantage are to be found in management's ability to consolidate corporate-wide technologies and production skills into competences that empower individual businesses to adapt quickly to changing opportunities'. The strategic purpose for launching a manufacturing CI initiative is to build a capability to speedily and efficiently effect improvements to the operating routines of a firm and to install new ones. To develop such a capability, senior management must provide the organisational vision needed to guide the setting of both the business and operational performance improvement objectives, including those for CI. In addition, senior management must enable the development of an infrastructure that can ensure the sustainment of congruence between the manufacturing strategic objectives of a business and the continuous improvement in the performance of its production processes and people (Anand et al. 2009). 


\subsection{Developing a process CI capability}

The key management decisions that enable the development of a process to support CI initiatives within a factory are those that derive from the purpose category of management decisions. These are infrastructure design decisions taken to maintain congruence between the manufacturing strategic objectives of a business and the choice of continuous improvement projects for implementation.

Bateman (2005) emphasises the necessity to have a supportive infrastructure in place to enable the sustainment of a CI initiative. However, no details are given on the elements that constitute this supportive CI management infrastructure, but a practical procedure is proposed to encourage shop floor employees to suggest ideas for performance improvement: 'This can typically be managed using a five to ten minute team briefing at the beginning (or end) of each shift' (Bateman 2005, 269).

A theoretical maturity model has been previously proposed (Bessant, Caffyn, and Gallagher 2001) which defines a road map for the development of a CI capability within a business. The model details the progressive development of employee behaviour from purely performing individual production tasks to active participation in team working $\mathrm{CI}$ activities that require the sharing of knowledge for the systematic analysis and resolution of production problems. The weakness of the Bessant, Caffyn, and Gallagher (2001) model is that the development of employee behaviour required to support and sustain a CI initiative is depicted as a predefined sequence of behavioural change that ultimately results in the development of a learning organisation. No recognition is given to the possibility of the loss of the 'discretionary effort' to be made by shop floor employees in order to sustain a momentum of improvement (Graham 1995; Delbridge 1998). 
The research of Anand et al. (2009) has informed practitioners about two key issues that impact the successful development of a CI capability. The first is the need to install procedures for the generation and implementation of CI projects in parallel with training people on problem solving techniques and process performance improvement practices. The second is the significance of taking a holistic view of the process of CI initiative management (the collection, review and implementation of ideas generated as part of CI activities). Previous research has found that it is critical that an infrastructure is established to support its coordination and management (Anand et al. 2009; Eisenhardt and Martin 2000; Garvin 1993). A limitation of Anand et al.'s (2009) research methodology, which they have acknowledged, was that their case studies were based upon information gleaned from only two levels within the organisation, namely the top level CI executives and project leaders - shop floor employees were not interviewed. As a consequence, a valuable source of information about the practices to be employed to encourage the 'bottom-up' generation of CI ideas and the degree of their involvement in their implementation was not tapped. In their study, the only procedure employed to generate ideas for improvement derived from the regular holding of 'workshops for middle management' (Anand et al. 2009, 453).

A study by Galeazzo, Furlan, and Vinelli (2017) explored the key dimensions of organisational infrastructure, namely strategic alignment and team working, and their impact on sustaining a CI capability. They found that the ability to deploy business strategy into functional objectives and the strategic coordination of actions is critical to developing a CI capability.

Although previous research has identified a number of the enablers of CI capability development (Jorgensen, Boer and Gertsen 2003; Jorgensen, Hyland and Kofoed 2008; Jaca et al. 2012), there still remains a need for organisations to gain a 
better understanding of how their leaders can cultivate a culture where all employees are recognised as able to effect the CI of operating performance.

\subsection{Developing the people CI capability}

The launch of a CI initiative can sometimes only induce a short-lived increase in employee participation in CI project implementations (Kerrin 1999). Strauss (1998) has noted that not all employees are willing to participate in learning organisation development activities; indeed, a number of studies have reported workers withdrawing their 'discretionary effort' from problem solving activities (Graham1995; Delbridge 1998). How an initial momentum of improvement can be sustained is a phenomenon recommended for further research (Bateman 2005).

Several researchers (Jorgensen, Boer, and Gertsen 2003; Garcia-Sabater, MarinGarcia and Perello-Marin 2012; Jaca et al. 2012) have identified a number of CI enablers, see Table 1.

Table 1. CI enablers (based on Garcia-Sabater, Marin-Garcia, and Perello-Marin (2012); Jaca et al. (2012); Jorgensen, Boer and Gertsen (2003)

\begin{tabular}{|l|}
\hline Management commitment and involvement \\
\hline Improvement programme objectives linked to strategy \\
\hline Achievement and implementation of results \\
\hline Use of appropriate methodology \\
\hline Management style consistent with CI \\
\hline Resources \\
\hline Adequate training \\
\hline Team organisation \\
\hline Training in CI tools \\
\hline Team development and training \\
\hline Methods for evaluation of CI \\
\hline Systems and procedures to support CI \\
\hline Mechanisms to support learning and knowledge sharing \\
\hline
\end{tabular}




\begin{tabular}{|l|}
\hline Problem-solving tools and checklists \\
\hline Communication of CI programme results \\
\hline Facilitator \\
\hline Selection of the appropriate areas for improvement \\
\hline Suggestion systems \\
\hline Recognition/incentive systems \\
\hline
\end{tabular}

As Table 1 shows, many of the listed enablers are linked to employee skills and knowledge development, and team working.

A number of other studies have been carried out that focused on the people management policies required for CI initiative sustainment. Jorgensen, Hyland and Kofoed (2008; see also Jurburg et al. 2015) identified the need for reward/recognition systems to encourage CI activity participation including the use of different incentives to encourage knowledge sharing by front line employees (Siemen, Roth, Balasubramanian and Anand 2009). Barton and Delbridge (2004) have examined not only the need to establish appropriate policies for employee training and development in CI practices, but also the need for HR policies that encourage the application of their 'discretionary effort' (Graham 1995; Delbridge 1998) for CI idea generation and implementation.

A number of other studies have identified and defined, in abstract terms, practices and processes that have been adopted to support and sustain a CI initiative (Aloini, Martini and Pellegrini. 2011). Their reported findings consist of recommended practices that have been found to facilitate continuous improvement but few discuss their interdependencies within a CI infrastructure. These additional enablers of CI are listed in Table 2.

Table 2. CI initiative sustainment practices (partly based on Glover et al. (2013), Jaca et al. (2012); Garcia-Sabater, Marin-Garcia and Perello-Marin (2012)) 


\begin{tabular}{|c|c|}
\hline $\begin{array}{l}\text { 1. Displaying metrics, charts, etc. } \\
\text { in work area }\end{array}$ & $\begin{array}{l}\text { Magdum and Whitman (2007); Bateman } \\
\text { (2005); Vitalo, Butz, and Vitalo (2003); Mika } \\
2002\end{array}$ \\
\hline 2. Follow-up meetings & $\begin{array}{l}\text { Martin and Osterling (2007); Ortiz (2006); } \\
\text { Montabon (2005); Mika (2002); Palmer } \\
\text { (2001); Foreman and Vargas (1999); Heard } \\
\text { (1999) }\end{array}$ \\
\hline $\begin{array}{l}\text { 3. } 30,60 \text {, and } 90 \text { day follow-up } \\
\text { reports to management }\end{array}$ & Destefani (2005) \\
\hline 4. Use of audits and auditing tools & $\begin{array}{l}\text { Magdum and Whitman (2007); Martin and } \\
\text { Osterling (2007) }\end{array}$ \\
\hline 5. Documentation of improvement & Miller (2005) \\
\hline $\begin{array}{l}\text { 6. Measurement system to } \\
\text { monitor improvement }\end{array}$ & $\begin{array}{l}\text { Bateman (2005); Bateman and Rich (2003); } \\
\text { Eguren et al. (2012) }\end{array}$ \\
\hline 7. Time for $5 \mathrm{C}$ & Bateman (2005) \\
\hline 8. Rewards to keep commitment & $\begin{array}{l}\text { Jorgensen, Hyland, and Kofoed (2008); Jaca et } \\
\text { al. (2012) }\end{array}$ \\
\hline 9. CI Manager & $\begin{array}{l}\text { Garcia-Sabater, Marin-Garcia and Perello- } \\
\text { Marin (2012) }\end{array}$ \\
\hline
\end{tabular}

The literature review has enabled the recognition of the need for further research into two CI initiative management issues. The first is a need to gain more comprehensive understanding of the process of CI initiative management, in particular, the sequence of recommended practices that enable the 'bottom-up' generation and evaluation of process improvement ideas. Also, what information feedback practices are required to inform proposers of the outcome of their CI suggestions and to encourage the submission of more CI ideas. The second is what causes the gradual loss of a momentum of continuous process improvement within an operation. This study was designed to investigate these two critical CI initiative management phenomena.

\section{$3 \quad$ Research aim and methodology}

The aim of the research was to identify the key management decisions that enable the sustainability of a CI initiative. To accomplish this aim required a study of the practices and procedures employed by the management and workforce of a plant to enable the CI 
of their operations. Of specific interest was the management of the submission, review and implementation of CI proposals raised by shop floor employees . The conduct of this study has been guided by the interpretivist paradigm (Collis and Hussey 2009).

\subsection{Case research methodology}

Case research was selected because of the two recognised strengths of this research methodology (Meredith 1998):

'A phenomenon can be studied in its natural setting and meaningful, relevant theory generated from the understanding gained through observing actual practice' (Voss, Tsikriktsis and Frohlich 2002, 197).

Case research allows the questions why and how (Yin 1984) to be answered with a relatively full understanding of the nature and complexity of the complete phenomenon under investigation - especially when it comes to the application of a new technology or management practice (Childe 2011).

\subsection{Case selection}

The unit of analysis chosen for this study was a manufacturing plant that was autonomously managed. Plant management was therefore solely responsible for its CI initiative implementation. The two manufacturing sites chosen for this study were achieving significantly different levels of CI performance. Their selection enabled a study of the similarities and differences in their approach to CI initiative management and their consequences. They were also chosen because they were similar in several important characteristics, the most important of which was that a formal CI initiative launch had been made at the start of the programme implementation and that the CI initiative was to be implemented across the whole factory rather than piloted in one or two areas. Selection of the cases to study was also based upon a number of other 
manufacturing plant characteristics; the extent of manufacturing automation investment and the similarity in the information technology and human resources available to support a CI initiative. Table 3 lists the characteristics of each plant, excluding profitability, as this was considered confidential by Plant Management.

Table 3. Profiles of the two case study plants

\begin{tabular}{|c|c|c|}
\hline & $\underline{\text { Plant } 1}$ & $\underline{\text { Plant } 2}$ \\
\hline $\begin{array}{l}\text { UK Plant within a multisite } \\
\text { manufacturing company }\end{array}$ & Yes & Yes \\
\hline $\begin{array}{l}\text { Autonomously managed } \\
\text { manufacturing plant }\end{array}$ & Yes & Yes \\
\hline Profit or cost centre & Cost & Cost \\
\hline $\begin{array}{l}\text { Annual site turnover at the } \\
\text { time of the study }\end{array}$ & $£ 175 \mathrm{M}$ & $£ 52 \mathrm{M}$ \\
\hline $\begin{array}{l}\text { Total site manufacturing } \\
\text { costs at the time of the } \\
\text { study }\end{array}$ & $£ 140 \mathrm{M}$ & $£ 47 \mathrm{M}$ \\
\hline Number of products & 75 & 315 \\
\hline $\begin{array}{l}\text { Types of production } \\
\text { processes }\end{array}$ & $\begin{array}{l}\text { One-piece assembly line } \\
\text { flow producing electro- } \\
\text { mechanical products }\end{array}$ & $\begin{array}{l}\text { Batch production and } \\
\text { packaging of powder and } \\
\text { liquid products }\end{array}$ \\
\hline Number of employees & 262 & 268 \\
\hline $\begin{array}{l}\text { Number of production } \\
\text { related employees }\end{array}$ & 248 & 193 \\
\hline $\begin{array}{l}\text { Production employees } \\
\text { organisation and key } \\
\text { performance indicators }\end{array}$ & $\begin{array}{l}\text { Team leaders and } \\
\text { operators. Production line } \\
\text { KPIs }\end{array}$ & $\begin{array}{l}\text { Team leaders and } \\
\text { operators. Production line } \\
\text { KPIs }\end{array}$ \\
\hline
\end{tabular}

The most significant difference between the two plants was their contrasting performances at CI; one factory was achieving annual increases in reduced manufacturing costs as a result of its CI activities, the other the opposite. The management of both plants had chosen to launch their CI initiatives within their manufacturing operations approximately five years prior to collaboration with this study. 
How the two plants were managed was similar in more ways to those detailed in Table 3. Induction training on the concept of CI was provided at both sites prior to the launch of their CI initiatives. The management of both plants were administering a reward and recognition scheme, based upon the cost savings achieved as a consequence of CI project implementation. For this reason, manufacturing cost savings resulting from CI activities within each plant were tracked and recorded. The researchers were therefore able to collect data on the annual plant manufacturing cost savings resulting from CI project implementations.

\subsection{Conducting the case studies}

An overview of the case research procedure followed for this study is detailed in Figure

1. Great care has been taken to avoid the pitfalls of case research by following established good practice in the design of a rigorous, precise and objective research instrument (see for example, Eisenhardt 1989; Yin 1984). The interview questionnaire that forms part of the research protocol is detailed in Appendix A, and the final page of this Appendix details the CI references used to design the Interview Pro Forma. 


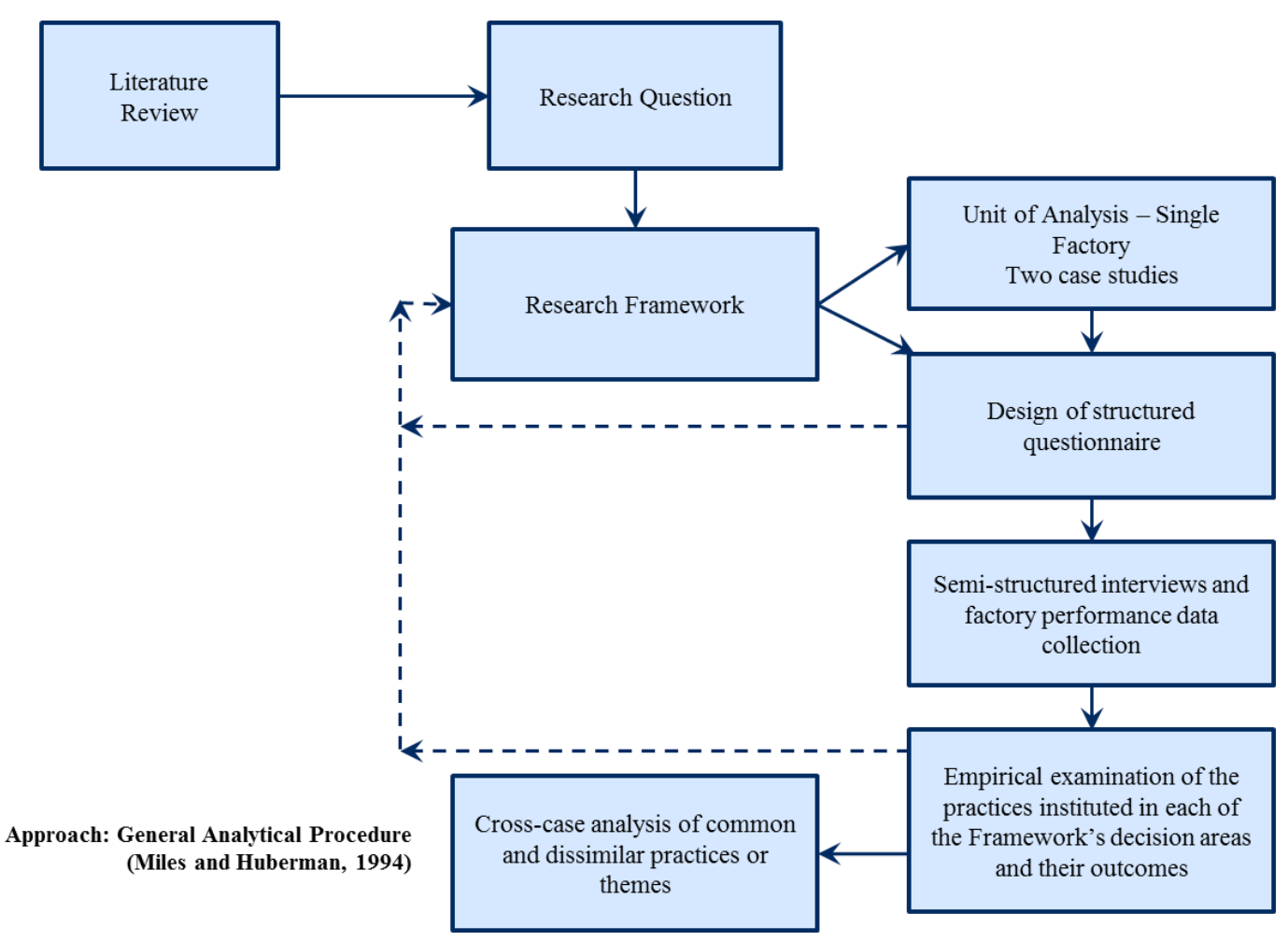

Figure 1. Case study research methodology

The interview questionnaire was structured to investigate three broad categories of CI programme management decisions: the purpose for initiating a CI capability development programme, the process designed for its execution, and the people management policies and procedures instigated to support its administration. These three broad categories of CI programme management decisions were chosen because sustained CI requires the treatment of people as knowledge resources and because their participation in the discovery of better methods to execute processes is encouraged in order to accomplish broader organisational purposes (Anand et al. 2009).

The case studies consisted of in-depth interviews with members of the site management team and shop floor employees. Prior to the one day visit made to each of the two manufacturing sites, the senior management of the site was sent a request for permission to interview the following site personnel: 
(1) The Plant Director or Manufacturing Director.

(2) A plant manufacturing manager.

(3) A functional manager responsible for either supply chain management or product quality.

(4) A manager responsible for human resource management.

(5) A Trade Union representative or Staff Association representative.

(6) Two manufacturing team leaders.

(7) Eight manufacturing team employees; four from two different production lines or cells.

The plant was also asked to provide operational performance data and background information about the plant, for example, its production volumes and manufacturing technologies used.

Each of the interviews carried out lasted 1 to $1 \frac{1}{2}$ hours and the responses were digitally recorded. In total, 30 interviews were carried out and the interviewee responses were transcribed. Key responses which evidence our theoretical contributions have been selected and listed by plant, the question asked and the seniority of the responder in Appendix B (Eisenhardt 1989). A team of three researchers conducted the interviews and they also carried out extensive observations of the factory floor.

Data triangulation was accomplished through interview responses and the collection of company data on manufacturing and employee performance. In addition, direct observations were made of production procedures and practices, manufacturing performance boards, improvement project boards and CI project tracker displays. Each plant Director also received a feedback report which summarised the findings of the research team. 
The method used to measure the CI performance of each firm was the total manufacturing cost savings resulting from CI ideas implementation over a period of four to five years prior to carrying out this study.

\section{$4 \quad$ Results}

The factory (Plant 1) of Company 1 is part of an international manufacturing network of ten plants. The plant has several assembly lines, a metal press shop and a paint area. The genesis of the development of a CI capability in this company was the implementation of a new manufacturing strategy, led by the Manufacturing Director, which included training the Production Team leaders of the plant in VSM (Value Stream Mapping) and six sigma tools and techniques to yellow belt standard. The outcome of this initiative was the completion of 20 major production line efficiency improvement projects over a three year period. The results of these activities are shown for Years 1 to 3 on Figure 2. Only limited shop floor participation in the scheme was accomplished. At this time, no other team member of Production Teams received any similar types of training on problem solving techniques. However, this was introduced in the 12 months prior to this study. It is during this last 12 month period that daily production problem meetings and the suggestion scheme were introduced.

The factory (Plant 2) of Company 2 has numerous ingredient mixing and packaging lines which produce packaged powder and liquid products. The plant is also part of a manufacturing network, albeit much smaller. The genesis of the development of a CI capability in this company was its owners observed that 'they could see people on the shop floor were interested in improving the performance of the business'. Accordingly a number of employees were selected, in October 2009, to attend an external training course on Lean Six Sigma practices. The internal training of all shop floor employees consisted of training on basic lean operations and problem solving 
tools and techniques such as 5S, PDCA and brainstorming. A Kaizen hour (see Table

2) in production time was instituted for shop floor employees to discuss actions required to eradicate production line stoppages and product quality problems (see answers to

Question 16(a) on Appendix B). The means of identifying the need for CI team action was informed through the introduction of a red tag system. Management found that the operators were not only good at identifying production problems but also at offering solutions. All shop floor employees are targeted to submit four CI proposals per annum.

\subsection{Overview of the two case study firms and their CI initiative launches}
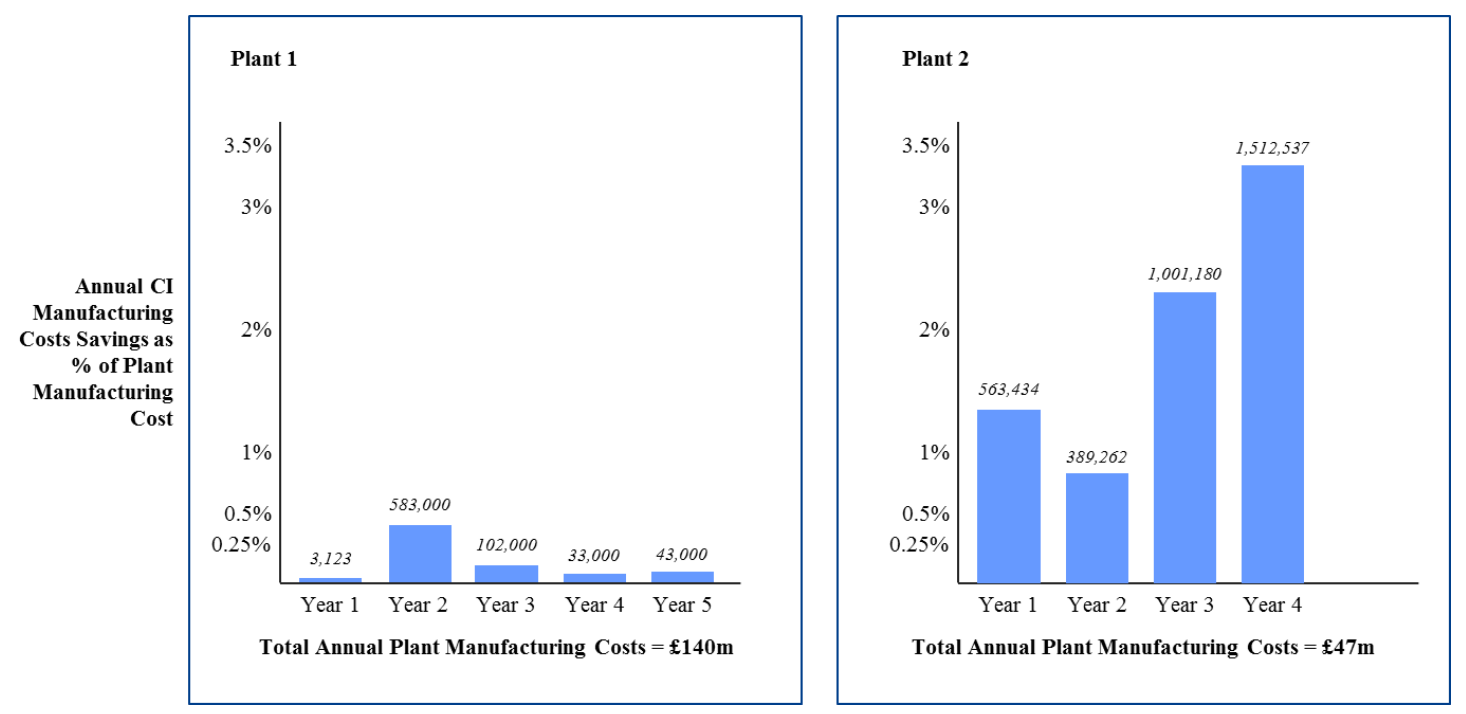

Figure 2. CI initiative annual cost savings as a percentage of annual plant manufacturing costs

Figure 2 shows the manufacturing cost savings achieved by the two plants studied. The cost savings are presented as percentages of plant total manufacturing costs. It is clear from Figure 2 that the management of Plant 1 succeeded initially in motivating its workforce to participate in its CI activities but were unable to sustain their commitment to do so. It is equally clear, from Figure 2, that the management of Plant 2 not only inspired its workforce to engage in CI activities but was also able to sustain their active 
involvement. The following details the differences that were found in their methods of managing the CI initiatives.

\subsection{Cross-case analysis of the CI initiative people management}

To build a momentum of improvement within an operating environment requires that all employees possess both the knowledge and motivation to participate in process change projects and to understand that their participation is valued (see Table 1). The levels of commitment given to CI programme participation by the workforce of the two plants studied can be deduced from their answers to Questions 24 and 25 in Appendix B. The answers given to Question 24 inform the differences in design of the two reward and recognition schemes of the two plants. Both are graded reward and recognition schemes but one gives a financial reward irrespective of its impact upon performance improvement. The other is graded according to the process performance improvement achieved. In addition, in Plant 2, the awards are formally presented (see Table 1). It is clear from the answers given to Question 9(a) in Appendix B that in Company 1 insufficient feedback is provided on the results of CI suggestions made by shop floor employees. However, feedback on the outcomes of CI suggestions implemented and the establishment of a reward and recognition system have been found to be a key to CI initiative sustainment (see Table 2). They can have either a negative or a positive impact on the 'discretionary effort' needed to be made by employees to successfully resolve production problem issues (Graham 1995; Delbridge 1998). The answer given to Question 9(a) by shop floor employees of Company 1 suggest that the incentive to make that discretionary effort has been lost (see Table 2). However, Figure 2 shows that it was being made during Year 2 of the CI initiative of Company 1.

The most revealing answer given to the level of management commitment and involvement in the CI initiative of each firm was given in answer to Question 25 (see 
Appendix B). In Company 1, some shop floor employees became disenchanted with participation in the CI initiative because 'you can see from the system that nobody is doing something with the idea'. The answers given to these same questions by Plant 2 shop floor employees confirm a higher level of commitment to the process of CI idea initiation and its implementation management. This suggests that they recognise the value company management attribute to their engagement in the CI project implementation. These answers confirm the significance of management commitment and involvement as a key enabler of CI (see Table 1).

\subsection{Cross-case analysis of the CI programme process management}

The two companies studied adopted very different approaches to managing the maintenance of congruence between the strategic objectives of the business and those set for their CI initiatives. Company 1 stated that productivity improvement was its manufacturing strategy objective (see answer to Question 2 in Appendix B). Company 2 adopted a more holistic approach by applying Hoshin Matrix disciplines to maintain congruence between its CI initiative and business objectives (see answer to Question 2 on Appendix B). Such an approach is considered to be a CI enabler, as detailed in Table 1. How the CI management process is designed to encourage employees to initiate and submit ideas for performance improvement and how they are supported during CI project implementation (see Table 1) is explained in answers to Questions 9(a) and 10(b) in Appendix B. It would seem that the Company 1 adopts a more 'topdown' approach to CI proposal submission, review and implementation management (see Question 9(a), Appendix B). This is in contrast to Company 2 which seems to adopt practices that are designed to elicit the participation of all its employees in both the origination and implementation of ideas put forward by them. Prompt feedback on the results of manufacturing performance improvement projects is critical for building 
and maintaining a momentum of improvement (see Table 1), as clearly emphasised by the response given by one shop floor employee of Plant 1 and detailed in the answers given to Question 9(a).

\subsection{Cross-case analysis of CI programme purpose}

To successfully launch a CI programme within a manufacturing plant requires the acceptance, by its workforce, that there is congruence between the vision for both business and plant manufacturing performance improvements (see Table 1). This study found an important difference in the defined visions for the two plants studied (see answers to question 1 on Appendix B). The critical difference was the extent to which the senior management of these plants considered in what ways their plant workforce could contribute to the achievement of their vision for the plant. The management of Plant 2 expressed a more inclusive role for the employees to enable manufacturing performance improvement. Also investigated was what manufacturing performance objectives had been set, at the time of the study, and how these could be attained. Again the answers given to this question differ (see answers to Question 2 in Appendix B). The management of Plant 2 perceive that empowered shop floor employees can make a significant contribution to the achievement of manufacturing performance objectives. Shop floor employees of Company 1 thought that targeted Key Performance Indicators (KPIs) were the drivers of manufacturing performance improvement. They did not express any view on how they could make a contribution to their achievement other than fulfil their designated production role.

The hierarchical listing of responses, given by the employees of the two firms studied, has enabled a clarification of their different levels of understanding of the business vision and the roles of employees in the achievement of the manufacturing objectives of their company. Greater emphasis on employee empowerment has been given by the 
management of Plant 2 than Plant 1. This is exemplified by the comment made by a Team Leader in Plant 1, who attributed the satisficing performance of the factory at CI to the company, which had not sufficiently acknowledged the value of (shop floor) employees (see the answer to Question 25 in Appendix B).

\section{$5 \quad$ Discussion and conclusions}

This research has been focused on answering the research question: what are the key management decisions that enable the sustained continuous improvement of operational performance? From the findings of this case research, we make two contributions to CI programme management. First, based on the evidence of practices instituted by the two firms studied, we identify five CI programme management factors that we have found enable CI initiative sustainment. The first factor is that the CI of operational performance should be considered as a Key Performance Indicator (KPI). It should be routinely monitored, reported and its performance visually displayed (see Table 2) as are plant safety, quality, productivity and delivery. The repeated reporting of this KPI will engender a culture of collective responsibility for CI, similar to that established for safety and quality management (Bateman 2005). Consequently, we recommend that CI cost saving objectives should be set along with the others that constitute the KPIs of the plant and managed in the same manner. This was a practice employed by the management of Plant 2. The plant management also designated a maximum amount of weekly production time for employees to discuss and prepare proposals for CI as a means of facilitating the achievement of their CI cost savings objectives.

The second CI programme management factor is to develop an employee empowerment culture in which the manufacturing performance improvement achievements of shop floor employees and team leaders are formally reported to all within the plant and celebrated (see Table 1). Contrary to the views expressed by the 
interviewees of the Anand et al. (2009) study but consistent with those reported in Garcia-Sabater, Marin-Garcia, and Perello-Marin (2012), our study findings lead us to conclude that an appropriately designed reward and recognition scheme does have a positive influence on the discretionary effort (Graham 1995; Delbridge 1998) made by employees to support a company CI programme (see answers given to Questions 24 and 25 in Appendix B). The inconsistency in the findings of these two previous studies may be attributable to the cultural differences between those who participated in them. It is clear from the results of the interviews carried out for this research that the design and management of the reward and recognition system had a profound impact on the motivation of shop floor employees to actively engage in CI activities.

The third CI programme management factor, and the engine of a momentum to continuously improve plant manufacturing performance, is the daily meetings scheduled to review the manufacturing performance of the previous day and to discuss actions required to resolve or eliminate any production problems encountered. The findings of our study suggest that the adoption of a tiered structure of daily manufacturing problems and performance review meetings (shop floor, team leaders and production management) enables both reaction speed to production problems resolution and proposed CI ideas review. The management of the capacity needed to action approved CI ideas can be accomplished through a CI project tracker board.

The fourth CI programme management factor is the communication process (Jaca et al. 2012), notably that devised to manage the acceptance or rejection of CI proposals, which should be devolved, transparent and efficient. Speed of feedback on decisions made on CI ideas motivates and builds a momentum of improvement. Figure 2 shows the levels of savings achieved by Plants 1 and 2 following the promotion of a company CI initiative by their management. Given the histories of the two plants and the age profiles of their employees, little difference in the positive outcomes of these CI 
programme promotions is evident during the first full year of their CI programmes (this is year 2 for Plant 1). However, it is clear from the research findings that the management of Plant 1 lost the initial momentum that it had developed to improve its manufacturing performance because of its poor CI programme management. What is critical to sustaining the initial momentum generated by a CI programme launch is the perception that shop floor employees have of the value that senior management attribute to their involvement in the programme (see answers to Questions Q1, Q9(a) and Q25).

The fifth CI programme management factor is the inclusion of employee empowerment in the strategic plan (Jaca et al. 2012), specifically, its inclusion in the company vision statement is important. Public celebrations, for example, emphasise the significance that the senior management of the company attribute to employee involvement in manufacturing performance improvement.

The second contribution to CI programme management is the development of a comprehensive CI programme management model which is detailed in Appendix C. The five factors highlighted above have been incorporated into the new model, and the model details a 'bottom-up' procedure for the generation of improvement ideas and the management of their implementation. To avoid muddling through CI programme management (Jorgensen, Boer, and Gertsen 2003), the new model is presented as a guide to practitioners to illustrate the sequential interdependencies of the elements of CI implementation and the feedback of information needed for its support and sustainment (Garcia-Sabater, Marin-Garcia, and Perello-Marlin 2012). The model consists of three elements, starting with people management, which includes activities such as recruitment, assessment of team working ability and CI knowledge and skills development. Employees are encouraged, by reward and recognition policies, to generate CI ideas which can enable them to meet their KPI objectives, which should also include the $\mathrm{CI}$ of manufacturing performance. The process of CI management 
constitutes the second element of the model. Its key feature is the three tier sequence of daily meetings to resolve any production problems encountered, to review CI suggestions, and to promptly inform the initiator of a CI proposal about the outcome of its management review. This is to ensure that employees are motivated to sustain their active participation in CI proposal submission. Business purpose is the third element of the model which reviews the consistency of implemented CI ideas with the achievement of the business and manufacturing performance objectives and the business development vision. Again, feedback is given to all employees on factory CI achievements.

An important issue that practitioners must consider before expending the resources required to launch and sustain a $\mathrm{CI}$ initiative, is whether it can prove to be economically beneficial. In the process of collecting manufacturing performance improvement data, we also collected data on the manufacturing cost savings achieved through the CI activities of each firm studied. Using these data, we have analysed the short-term economic benefits that can be realised by the continuous improvement of production operations through scheduling one hour of non-productive time per week for operations performance review and improvement idea generation (Appendix D). Our analysis suggests that when a CI capability is fully embedded within a business these benefits can exceed the value of the production output sacrificed during this time. This analysis excludes the longer-term benefits to the competitiveness of a firm that can be realised by implementing $\mathrm{CI}$ ideas.

The limitations of this research are those that are intrinsic to adopting a case research methodology. Our cases have been limited to manufacturing companies that are sited in the U.K. Therefore, the generalisation of the conclusions drawn from our case research cannot be assumed for companies in different industrial sectors and located in other regions of the world. However, the careful selection of our research 
aim and the firms in which we carried out our investigations could improve the external validity of our conclusions. Further research is required to test the applicability of the proposed model of CI programme management in other industrial sectors, for example, the processing industries. Further research is also required to ascertain whether cultural differences have an influence upon the need to establish reward and recognition practices to motivate employee participation in the CI programme.

\section{Acknowledgements}

The Authors gratefully acknowledge the collaboration and participation of the management and employees of the two firms that were actively involved in this case research. We wish to also express our gratitude for the detailed and very helpful comments on the paper content made by two anonymous reviewers which, taken together, have greatly improved the paper. 


\section{References}

Aloini, D., A. Martini, A. and L. Pellegrini. 2011. "A Structural Equation Model for Continuous Improvement: A Test for Capabilities, Tools and Performance." Production Planning and Control 22 (7): 628-648.

Anand, G., P.T. Ward, M.V. Tatikonda, and D.A. Schilling. 2009. "Dynamic Capabilities Through Continuous Improvement Infrastructure.” Journal of Operations Management 27: 444-461.

Barton, H., and R. Delbridge. 2004. "HRM in Support of the Learning Factory: Evidence From the US and UK Automotive Components Industries." International Journal of Human Resource Management 15 (2): 331-345.

Bateman, N. 2005. "Sustainability: The Elusive Element of Process Improvement." International Journal of Operations and Production Management 25 (3): 261276.

Bateman, N., and N. Rich. 2003. “Companies' Perceptions of Inhibitors and Enablers for Process Improvement Activities.” International Journal of Operations and Production Management 23 (2): 185-199.

Beer, M., S.C. Voelpel, M. Leilpel, and E. B. Tekie. 2005. "Strategic Management as Organizational Learning: Developing Fit and Alignment Through a Disciplined Process.” Long Range Planning 38 (5) 445-465.

Bessant, J., and S. Caffyn. 1997. "High-Involvement Innovation Through Continuous Improvement.” International Journal of Technology Management 14 (1): 7-28.

Bessant, J., S. Caffyn, and M. Gallagher. 2001. “An Evolutionary Model of Continuous Improvement Behaviour." Technovation 21 (2): 67-77.

Childe, S. J. 2011. Case Studies in Operations Management. Production Planning and Control, 22(2), pp.107-107.

Collis, J., and R. Hussey. 2009. Business Research: A Practical Guide for Undergraduate and Postgraduate Students, $3^{\text {rd }}$ ed. Hampshire: Palgrave Macmillan.

Cua, K.O., K.E. McKone, and R.G. Schroeder. 2001 "Relationships Between Implementation of TQM, JIT, and TPM and Manufacturing Performance." Journal of Operations Management 19 (6): 675-694.

Davidson, J.M., A. Clamen, and R.A. Karol. 1999. "Learning From the Best New Product Developers.” Research Technology Management 42 (4) 12-18. 
Delbridge, R. 1998. Life on the Line in Contemporary Manufacturing, Oxford: Oxford University Press.

Delbridge, R., and H Barton. 2002. "Organizing for Continuous Improvement: Structures and Roles in Automotive Components Plants". International Journal of Operations \& Production Management 22 (6): 680-692.

Destefani, J. 2005. "Lean Propels Turbine Engine Production.” Manufacturing Engineering 134 (5): 157-166.

Eisenhardt, K.M. 1989. "Building Theory From Case Study Research.” Academy of Management Review 14 (4): 532-550.

Eisenhardt, K.M., and J.A. Martin. 2000. “Dynamic Capabilities: What Are They?” Strategic Management Journal 21 (October-November Special Issue): 11051121.

Eguren, J.A., U. Elorza, and L. Pozueta. 2012. Model/Framework for Addressing Continuous Improvement Projects Effectively and Efficiently Using Six Sigma Methodology. Case study of automotive auxiliary company. Management and Production Engineering Review 3(4): 35-46.

Forman, C.R., and D.H. Vargas. 1999. “Affecting the Value Chain Through Supplier Kaizen." Hospital Materiel Management Quarterly 20 (3): 21-27.

Galeazzo, A., Furlan, A. and Vinelli, A. 2017. "The Organizational Infrastructure of Continuous Improvement - An Empirical Analysis.” Operations Management Research 10 (1): 33-46.

Garcia-Sabater, J.J., J.A. Marin-Garcia, and M.R. Perello-Marin. 2012. "Is Implementation Of Continuous Improvement Possible? An Evolutionary Model of Enablers and Inhibitors." Human Factors and Ergonomics in Manufacturing \& Service Industries 22 (2): 99-112.

Garvin, D.A. 1993. "Manufacturing Strategy Planning." California Management Review 35 (4): 85-106.

Glover, W.J., W.H. Liu, J.A. Farris, and E. M. Van Aken, 2013. Characteristics of Established Kaizen Event Programs: An Empirical Study. International Journal of Operations \& Production Management, 33(9), pp.1166-1201

Graham, L. 1995. On the Line at Subaru-Isuza. New York, Ithaca: ILR Press.

Heard, E. 1999. "Rapid-Fire Improvement With Short-Cycle Kaizen.” Hospital Materiel Management Quarterly 20 (4): 15-23.

Imai, M. 1986. Kaizen. New York: McGraw Hill. 
Jaca, C., E. Viles, R. Mateo, and J. Santos. 2012. "Components of sustainable improvement systems: theory and practice." The TQM Journal 24 (2): 142-154. Jorgensen, F., H. Boer, and F. Gertsen. 2003. “Jump-Starting Continuous Improvement Through Self-Assessment." International Journal of Operations and Production Management 23 (10): 1260-1278.

Jorgensen, F., P. Hyland, and L.B. Kofoed. 2008. "Examining the Role of Human Resource Management in Continuous Improvement." International Journal of Technology Management 42 (1/2): 127-142.

Juran, J.M. 1992. Juran on Quality by Design: The New Steps for Planning Quality into Goods and Services. New York: Free Press.

Jurburg, D., Viles, E., Jaca, C., \& Tanco, M. (2015). Why are Companies Still Struggling to Reach Higher Continuous Improvement Maturity Levels? Empirical Evidence From High Performance Companies. The TQM Journal, 27(3), 316-327

Kerrin, M. 1999. “Continuous Improvement Capability: Assessment Within One Case Study Organisation." International Journal of Operations and Production Management 19 (11): 1154-1167.

Lareau, W. 2003. Office Kaizen: Transforming Office Operations into a Strategic Competitive Advantage, Milwaukee, WI: ASQ Quality Press.

Leonard-Barton, D. 1992. "The Factory as a Learning Laboratory." Sloan Management Review: 23-38.

Magdum, V., and L. Whitman 2007. "Sustainability of Kaizen Events: An Independent Study." Working Paper, Department of Industrial and Manufacturing Engineering, Wichita State University, Wichita, KS, Fall.

Martin, K., and M. Osterling 2007. The Kaizen Event Planner. New York: Productivity Press.

Mauri, F., M. Garetti, and A. Gandelli. 2010. “A Structured Approach to Process Improvement in Manufactured Systems." Production Planning and Control 21 (7): 695-717.

Meredith, J. 1998. "Building Operations Management Theory Through Case and Field Research." Journal of Operations Management 16: 441-454.

Mika, G.L. 2002. Kaizen Event Implementation Manual, $2^{\text {nd }}$ ed. Wake Forest, NC: Kaizen Sensei.

Miller, B.D. 2005. "Implications of Motivation Research for Practitioners of Kaizen Blitz." Proceedings of the 2005 Industrial Engineering and Research 
Conference, Atlanta, GA, Institute of Industrial Engineers, Norcross, GA, CDROM.

Montabon, F. 2005. "Using Kaizen Events for Back Office Processes: The Recruitment of Frontline Supervisor Co-Ops." Total Quality Management and Business Excellence 16 (10): 1139-1147.

Nonaka, I., 1988. “Towards Middle-Up-Down Management: Accelerating Information Creation.” Sloan Management Review 29 (3): 9-18.

Ortiz, C. 2006. “All-Out Kaizen: A Continuous Improvement Plan Delivers Change to the Production Floor... and Dollars to the Bottom Line." Industrial Engineer 38 (4): 30 .

Palmer, V.S. 2001. "Inventory Management Kaizen", $2^{\text {nd }}$ International Workshop on Engineering Management for Applied Technology (EMAT 2001) Proceedings in Austin Prahalad, C.K., and G. Hamel. 1990. "The Core Competence of the Corporation." Harvard Business Review May-June: 79-91.

Rapp, C., and J. Eklund. 2002. "Sustainable Development of Improvement Activities The Longer-Term Operation of a Suggestion Scheme in a Swedish Company." Total Quality Management 13 (7): 945-969.

Rummler, G.A., and A.P. Brache. 1995. Improving Performance: How to Manage the White Space on the Organization Chart. Hoboken NJ: Jossey-Bass.

Siemen, E., A.V. Roth, S., Balasubramanian, and G. Anand. 2009. "The influence of psychological safety and confidence in knowledge on employee knowledge sharing." Manufacturing and Service Operations Management 11 (3): 429-447.

Strauss, G. 1998. “An Overview” in F. Heller, E. Pusic, G. Strauss, and B. Wilpert eds. Organizational Participation; Myth and Reality. Oxford: Oxford University Press: 8-39.

Teece, D.J., 2007. “Explicating Dynamic Capabilities: The Nature and MicroFoundations of (Sustainable) Enterprise Performance." Strategic Management Journal 28 (11): 1319-1350.

Upton, D. 1996. "Mechanisms for Building and Sustaining Operations Improvement." European Management Journal 14 (3): 215-28.

Vitalo, R.L., F. Butz, and J.P. Vitalo. 2003. Kaizen Desk Reference Standard. Hope ME: Vitalo Enterprises. 
Voss, C., N. Tsikriktsis, and M Frohlich. 2002. "Case Research in Operations Management." International Journal of Operations and Production Management 22 (2): 195-219.

Witcher, B.J., and R. Butterworth. 2001. "Hoshin Kanri: Policy Management in Japanese-owned UK Subsidiaries.” Journal of Management Studies 38 (5) 651674.

Wu, C.W., and C.L. Chen. 2006. "An Integrated Structural Model Towards Successful Continuous Improvement Activity." Technovation 26 (5/6): 697-707.

Yin, R. 1984. Case Study Research. Beverly Hills CA: Sage Publications.

Zolo, M., and S.G. Winter. 2002. "Deliberate Learning and the Evolution of Dynamic Capabilities." Organization Science 13 (3): 339-351. 
Appendix A. Investigating Continuous Improvement Practice and Pitfalls

\section{Interview Pro Forma}

\section{General Information}

1. Is it $\mathrm{OK}$ if I record this conversation?

2. What is your name and job title?

3. a. What is your current role in the company?

b. Which production line/area do you mainly work in (or are responsible for)?

\section{The purpose for investing in the development of a CI capability}

Note: the bracketed numbers below which are not in bold, refer to the references following the pro forma i.e. they link the questions to their source. The numbers in bold are the interview questions.

\section{References Interview Questions}

1) 1. What do you understand to be the vision for how the factory will operate and improve in the future?

2) 2. What are the objectives of the manufacturing function to enable the vision for the performance of the factory to become a reality?

3) 4) 3. Who set the performance improvement objectives for the factory?

5) 6) 4. Have any factory performance improvement initiatives or activities been undertaken previously? (Ask for year). If so, for what purpose or purposes?

1) 5. Were these previous performance improvement initiatives successful or unsuccessful? If unsuccessful, what were the reasons?

7) 6. What do you consider to be the role of the Human Resource Management function of the Company in achieving the continuous improvement (CI) of manufacturing performance?

\section{Process}

8) 9) 7. How do Company manufacturing managers and employees learn about the CI practices that can improve manufacturing performance? (Probe for tools and techniques). 
5) 8. Who took the initiative to adopt the current continuous improvement practices being performed in the factory?

10) 9.a) How are CI initiatives or activities selected and coordinated?

10) 9.b) What are the main reasons for their selection?

10) 11) 10. a) Who selects team members for CI initiative teams?

10. b) When do the CI team meetings take place?

10. c) What approach do you follow when working on a CI project? (Probe to see what structured approaches they use)

12) How is data on performance improvement collected, reviewed and used for CI action planning?

13) How are successful process performance improvement changes to standard operating procedures shared with other production teams?

13) 13. How do you ensure that any new procedures or practices are consistently adhered to within your production area?

\section{People}

10) 14) When a colleague is recruited, should assessment be made of an individual's attitude to contributing to continuous performance improvement?

15. a) Who is responsible for approving or rejecting the implementation of ideas?

15. b) How long does this acceptance/rejection process take?

15. c) How is the decision to approve/reject a suggestion communicated to you?

16. a) Where do continuous improvement (CI) initiative ideas come from?

15) 16. b) Are standard procedures and practices, such as Kaizen or team problem solving discussions, followed or adopted to manage continuous improvement problem solving and process change practices?

15) 17. a) Who leads manufacturing performance improvement initiatives?

17. b) Are you given time to plan and implement approved performance improvement initiatives? 
17. c) If these planning meetings are not held regularly, what are the reasons?

17. d) Are improvement objectives set for the team within which you work? If so, are you formally informed of your team's achievements against those objectives?

10) 16) To what extent are CI teams cross-functional?

12) 19. Are internal customers and suppliers included in CI teams?

10) 17) 20. Is a CI initiative tracker used to report and display the progress of CI initiatives going on in the factory?

12) 21. What CI Initiatives in your production area have you participated in?

12) 22. Did you receive any training for your participation in CI initiatives? If so, what was it and who provided it?

12) 23. Is your involvement in $\mathrm{CI}$ initiatives set as a performance objective for you and reviewed during your annual personal performance review (PDR)?

24. Is there a company policy to reward individuals for their contribution to the CI activities of the company by:

a) A formal financial reward

b) A non-financial method of recognition, for example a team outing, family dinner etc.

c) Neither of the above, but personal development opportunities or promotion opportunities are discussed during an annual PDR to recognise CI team participation

d) Would it be more appropriate to adopt a team reward system instead of individual reward system?

25. Is there anything that you would like to add to our discussion of the continuous improvement activities carried out in the factory and which you feel is important to your involvement in them and understanding of the need for them?

Thank you for your time and for answering my questions. 
Key to the References used to design the Interview Pro Forma
1) Anand et al. (2009)
2) Beer et al. (2005)
3) Garvin (1993)
4) Witcher and Butterworth (2001)
5) Juran (1992)
6) Lareau (2003)
7) Jorgensen, Hyland, and Kofoed (2008)
8) Cua, McKone, and Schroeder (2001)
9) Teece (2007)
10) Imai (1986)
11) Davidson, Clamen, and Karol (1999)
12) Upton (1996)
13) Bessant and Caffyn (1997)
14) Leonard-Barton (1992)
15) Nonaka (1988)
16) Delbridge and Barton (2002)
17) Rummler and Brache (1995) 


\section{Appendix B. CI interview responses listed by organisational level}

Responses to interview questions on the strategic PURPOSE of the manufacturing function of the two organisations studied (Questions 1- 6 on the Interview Pro Forma) and the impact of implementing a continuous process improvement initiative on the achievement of their manufacturing aims and objectives

\begin{tabular}{|c|c|c|c|}
\hline $\begin{array}{c}\text { Definition of } \\
\text { issue } \\
\text { investigated }\end{array}$ & $\begin{array}{c}\text { Definition of } \\
\text { Pro Forma } \\
\text { questions }\end{array}$ & Responses given in Company 1 & Responses given in Company 2 \\
\hline \multirow[t]{2}{*}{$\begin{array}{l}\text { Management } \\
\text { decisions that } \\
\text { govern the } \\
\text { formulation and } \\
\text { communication } \\
\text { of } \\
\text { organisational } \\
\text { and project } \\
\text { goals for CI }\end{array}$} & $\begin{array}{l}\text { Q1: What do you } \\
\text { understand to be } \\
\text { the vision for how } \\
\text { the factory will } \\
\text { operate and } \\
\text { improve in the } \\
\text { future? }\end{array}$ & $\begin{array}{l}\text { Management: } \\
\text { "To be the leanest manufacturing plant in Europe - the } \\
\text { aim is to have } 50 \text { production employees to produce } \\
500,000 \text { units per annum." } \\
\text { Team Leaders: } \\
\text { "Full sustainability - to be profitable to keep the plant } \\
\text { open here in the UK." } \\
\text { Shop Floor Employees: } \\
\text { "Don't really know. To sell more units (of } \\
\text { production) to keep us going." }\end{array}$ & $\begin{array}{l}\text { Management: } \\
\text { "To be the best producer (in our industry) and to } \\
\text { empower our work force to deliver the KPIs of the plant." } \\
\text { Team Leaders: } \\
\text { "By using CI techniques such as morning meetings to } \\
\text { plan actions to eliminate process faults, to improve } \\
\text { efficiency." } \\
\text { Shop Floor Employees: } \\
\text { "Through meetings and briefings we learn what is } \\
\text { expected of us and how we are performing" }\end{array}$ \\
\hline & $\begin{array}{l}\text { Q2: What are the } \\
\text { objectives of the } \\
\text { manufacturing } \\
\text { function? }\end{array}$ & $\begin{array}{l}\text { Management: } \\
\text { "How we can increase the productivity of the site." }\end{array}$ & $\begin{array}{l}\text { Management: } \\
\text { "The Hoshin Matrix defines the key turnover, profit, } \\
\text { customer service and the employee culture targets." } \\
\text { "To be the No. } 1 \text { company within our industry through (a) } \\
\text { product quality and (b) performance improvement } \\
\text { through people and equipment by: } \\
\text { 1. Equipment performance improvement through } \\
\text { PDCAs, 5S, SOPs } \\
\text { 2. People improvement by empowering the staff to be } \\
\text { responsible for the equipment." }\end{array}$ \\
\hline
\end{tabular}




\begin{tabular}{|l|l|l|l|}
\hline $\begin{array}{l}\text { Definition of } \\
\text { issue } \\
\text { investigated }\end{array}$ & $\begin{array}{l}\text { Definition of Pro } \\
\text { Forma questions }\end{array}$ & \multicolumn{1}{|c|}{ Responses given in Company 1 } & \multicolumn{1}{c|}{ Responses given in Company 2 } \\
\hline $\begin{array}{l}\text { Management } \\
\text { decisions that } \\
\text { govern the } \\
\text { formulation and } \\
\text { communication } \\
\text { of } \\
\text { organisational } \\
\text { and project } \\
\text { goals for CI }\end{array}$ & $\begin{array}{l}\text { Q2: What are the } \\
\text { objectives of the } \\
\text { manufacturing } \\
\text { function? }\end{array}$ & $\begin{array}{l}\text { Team Leaders: } \\
\text { 'To build the product as economically as possible, } \\
\text { achieve customer satisfaction and to be profitable.' } \\
\text { Shop Floor Employees: } \\
\text { 'The company is run by (targeted) KPIs and these } \\
\text { continue to be the driver of the business' } \\
\text { '6\% (efficiency improvement) every year, health and } \\
\text { safety, 5S things.' }\end{array}$ & $\begin{array}{l}\text { Team Leaders: } \\
\text { 'We have performance boards on which there are targets } \\
\text { displayed and current performance reported' } \\
\text { Shop Floor Employees: } \\
\text { 'The lines need to be good at efficiency, obviously } \\
\text { continuous improvement on the line .... quality again, } \\
\text { health and safety and environment.' }\end{array}$ \\
\hline
\end{tabular}


Responses to questions on the PROCESS developed to manage the CI activities (Questions 8-13 on the Interview Pro Forma) of the two organisations studied

\begin{tabular}{|c|c|c|c|}
\hline $\begin{array}{c}\text { Definition of } \\
\text { issue } \\
\text { investigated }\end{array}$ & $\begin{array}{l}\text { Definition of Pro } \\
\text { Forma questions }\end{array}$ & Responses given in Company 1 & Responses given in Company 2 \\
\hline \multirow[t]{2}{*}{$\begin{array}{l}\text { Management } \\
\text { decisions that } \\
\text { govern the } \\
\text { selection, } \\
\text { planning and } \\
\text { implementation } \\
\text { of CI projects }\end{array}$} & $\begin{array}{l}\text { Q9(a): How are CI } \\
\text { initiatives or } \\
\text { activities selected } \\
\text { and coordinated? }\end{array}$ & $\begin{array}{l}\text { Management: } \\
\text { 'All projects are discussed at the Excom (Executive } \\
\text { Committee) meeting - major projects (monthly } \\
\text { meeting), smaller projects are detailed on the tracker } \\
\text { board/action list.' } \\
\text { Team Leaders: } \\
\text { 'The Kaizen scheme is computer based. People can } \\
\text { submit the idea electronically. Once the idea is } \\
\text { submitted, the MTL (Manufacturing Team Leader) } \\
\text { will evaluate the idea.' } \\
\text { Shop Floor Employees: } \\
\text { 'We now have a 5S/Kaizen coordinator. People have } \\
\text { to see their ideas adopted or to know why they } \\
\text { haven't been accepted. Managers are responsible for } \\
\text { reviewing the acceptability of ideas. More people } \\
\text { would be involved with suggesting ideas for } \\
\text { improvement with more feedback on their } \\
\text { suggestions'. }\end{array}$ & $\begin{array}{l}\text { Management: } \\
\text { 'Ideas first submitted to HR and then passed to me } \\
\text { (Production Manager). I review it and make a decision } \\
\text { on its implementation or not ... It is then reviewed by an } \\
\text { idea improvement committee to review its cost/benefit.' } \\
\text { Team Leaders: } \\
\text { 'Ideas are stored in the PDCA folders stored on the shop } \\
\text { floor. The PDCA contains information on the nature of } \\
\text { the problem, cost to implement and cost savings made. } \\
\text { Selection of improvement based on improving line } \\
\text { efficiency, reducing waste and quality improvement.' } \\
\text { Shop Floor Employees: } \\
\text { 'We are involved in the meetings every morning ... they } \\
\text { speak to us about the tags, the PDCAs, what } \\
\text { improvements we think we need. With your manager } \\
\text { involved, the engineering manager plus the quality } \\
\text { manager then you feel you are getting somewhere - they } \\
\text { are listening to you.' }\end{array}$ \\
\hline & $\begin{array}{l}\text { Q10(b): When do } \\
\text { the CI team } \\
\text { meetings take } \\
\text { place? }\end{array}$ & $\begin{array}{l}\text { Management: } \\
\text { 'Every morning we have a shop floor meeting at } 8.30 \\
\text { am - 'shop floor walk' - a plant performance meeting } \\
\text { (over the last } 24 \text { hours). This is a multi-disciplinary } \\
\text { management meeting.' } \\
\text { Team Leaders: } \\
\text { 'It depends on the size of the project - weekly.' }\end{array}$ & $\begin{array}{l}\text { Management: } \\
\text { 'The team will have an initial project planning meeting - } \\
\text { led by the idea generator. The (follow-up) meetings will } \\
\text { be planned to take place to minimise their impact on } \\
\text { production.' } \\
\text { Team Leaders: } \\
\text { 'We plan Kaizen hours into the production schedule and } \\
\text { to fit with when the engineers can attend.' }\end{array}$ \\
\hline
\end{tabular}




\begin{tabular}{|l|l|l|l|}
\hline $\begin{array}{l}\text { Definition of } \\
\text { issue } \\
\text { investigated }\end{array}$ & $\begin{array}{l}\text { Definition of Pro } \\
\text { Forma questions }\end{array}$ & \multicolumn{1}{|c|}{ Responses given in Company 1 } & \multicolumn{1}{c|}{ Responses given in Company 2} \\
\hline $\begin{array}{l}\text { Management } \\
\text { decisions that } \\
\text { govern the } \\
\text { selection, } \\
\text { planning and } \\
\text { implementation } \\
\text { of CI projects }\end{array}$ & $\begin{array}{l}\text { Q10(b): When do } \\
\text { the CI team } \\
\text { meetings take } \\
\text { place? }\end{array}$ & $\begin{array}{l}\text { Shop Floor Employees: } \\
\text { 'Teams meet initially once a week.' }\end{array}$ & $\begin{array}{l}\text { Shop Floor Employees: } \\
\text { 'Meetings will take place during work time. When } \\
\text { needed, no set time.' }\end{array}$ \\
\hline
\end{tabular}


Responses to questions on the PEOPLE management issues that have enabled the CI initiative implementation (Questions 14-24) of the two organisations studied

\begin{tabular}{|c|c|c|c|}
\hline $\begin{array}{l}\text { Definition of } \\
\text { issue investigated }\end{array}$ & $\begin{array}{l}\text { Definition of Pro } \\
\text { Forma questions }\end{array}$ & Responses given in Company 1 & Responses given in Company 2 \\
\hline $\begin{array}{l}\text { Management } \\
\text { decisions that } \\
\text { govern the } \\
\text { training, } \\
\text { motivation and } \\
\text { organisation of } \\
\text { employees to } \\
\text { participate in CI } \\
\text { projects }\end{array}$ & $\begin{array}{l}\text { Q16(a): Where do } \\
\text { continuous } \\
\text { improvement } \\
\text { initiative ideas } \\
\text { come from? }\end{array}$ & $\begin{array}{l}\text { Management: } \\
\text { 'Everybody - I am pretty sure everybody can make } \\
\text { improvements. Ideas are recorded in a databank for } \\
\text { review.' } \\
\text { Team Leaders: } \\
\text { 'Individuals will see opportunities in their normal } \\
\text { working day to improve things.' } \\
\text { Shop Floor Employees: } \\
\text { 'You pick it up while you are working. People who } \\
\text { have been on training courses see it, compared to } \\
\text { those who haven't been on the courses. Why do it } \\
\text { that way, why not another way which is quicker?' }\end{array}$ & $\begin{array}{l}\text { Management: } \\
\text { 'It's the staff - it's quite surprising what ideas are } \\
\text { generated even though we (the managers) have been } \\
\text { here } 20-30 \text { years and would not have thought of them.' } \\
\text { Team Leaders: } \\
\text { 'They come from brainstorming, Kaizen hours and team } \\
\text { members.' } \\
\text { Shop Floor Employees: } \\
\text { 'I suppose there is a knock-on effect, we have } \\
\text { implemented this idea now and it has shown an } \\
\text { opportunity for further improvement. I suppose we are } \\
\text { all looking for opportunities to improve how we do } \\
\text { things.' }\end{array}$ \\
\hline \multirow[t]{2}{*}{$\begin{array}{l}\text { Management } \\
\text { decisions that } \\
\text { govern the } \\
\text { training, } \\
\text { motivation and } \\
\text { organisation of } \\
\text { employees to } \\
\text { participate in CI } \\
\text { projects }\end{array}$} & \multirow[t]{2}{*}{$\begin{array}{l}\text { Q24: Is there a } \\
\text { company policy to } \\
\text { reward individuals } \\
\text { for their } \\
\text { contribution to the } \\
\text { CI activities of the } \\
\text { company? }\end{array}$} & $\begin{array}{l}\text { Management: } \\
\text { 'The Kaizen Scheme - } \\
\text { a) An improvement idea submitted receives a } \\
\text { reward }(£ 10) \\
\text { b) An idea implemented - reward is up to } 15 \% \text { of } \\
\text { annual cost savings } \\
\text { c) No direct saving - e.g., improved H\&S, a reward } \\
\text { is given as everybody’s bonus is CI } \\
\text { involvement.' } \\
\text { Team Leaders: } \\
\text { 'We offer £10 one off payment for an idea.' }\end{array}$ & $\begin{array}{l}\text { Management: } \\
\text { 'An individual's (proposed) idea is submitted, through } \\
\text { the Six Sigma Facilitator, to the (CI management) } \\
\text { committee. }\end{array}$ \\
\hline & & $\begin{array}{l}\text { Shop Floor Employees: } \\
\text { 'They just provide the bonus. No newsletter, no best } \\
\text { idea.' }\end{array}$ & $\begin{array}{l}\text { Shop Floor Employees: } \\
\text { 'Yes, there is a } £ 150 \text { reward for the best ideas for } \\
\text { improvement or contribution to CI. Winning a holiday } \\
\text { in a company owned house abroad. The management } \\
\text { recognise your contribution by personally thanking you.' }\end{array}$ \\
\hline
\end{tabular}


Reflective general comments made at the end of the interview

\begin{tabular}{|c|c|c|c|}
\hline $\begin{array}{c}\text { Definition of } \\
\text { issue } \\
\text { investigated }\end{array}$ & $\begin{array}{l}\text { Definition of Pro } \\
\text { Forma questions }\end{array}$ & Responses given in Company 1 & Responses given in Company 2 \\
\hline $\begin{array}{l}\text { Reflective } \\
\text { general } \\
\text { comments on } \\
\text { the company } \\
\text { management of } \\
\text { its CI initiative }\end{array}$ & $\begin{array}{l}\text { Q25: Is there } \\
\text { anything that you } \\
\text { would like to add } \\
\text { to our discussions } \\
\text { of the continuous } \\
\text { improvement } \\
\text { activities carried } \\
\text { out in the factory } \\
\text { and which you feel } \\
\text { is important to your } \\
\text { involvement and } \\
\text { understanding of } \\
\text { the need for them? }\end{array}$ & $\begin{array}{l}\text { Management: } \\
\text { 'You have to lead by example and give clear feedback } \\
\text { on achievements.' } \\
\text { Team Leaders: } \\
\text { 'We have a newsletter but we don't celebrate the ideas } \\
\text { people have had.' } \\
\text { Shop Floor Employees: } \\
\text { 'I have put } 2 \text { ideas in this year - I don't know what } \\
\text { has happened to these ideas. People can log into the } \\
\text { Kaizen system and see where their idea is. You can } \\
\text { see from the system that nobody is doing something } \\
\text { with the idea.' }\end{array}$ & $\begin{array}{l}\text { Management: } \\
\text { 'The main thing is getting them all done. If you don't } \\
\text { people will get turned off. We respond very quickly to } \\
\text { people's PDCA forms.' } \\
\text { Team Leaders: } \\
\text { 'Using CI practices, the line can be run more efficiently. } \\
\text { By reducing the downtime, work is easier and objectives } \\
\text { can be achieved which means you have a more satisfying } \\
\text { day.' } \\
\text { Shop Floor Employees: } \\
\text { 'Continuous improvement is important for the whole } \\
\text { business, the more ideas we put forward will help make } \\
\text { the company become more efficient and profitable. We } \\
\text { have seen this because this has created more work and } \\
\text { more jobs. It is also a really good place to work and I } \\
\text { really like working here.' }\end{array}$ \\
\hline
\end{tabular}




\section{Continuous Improvement Programme Management}

\section{People Management}

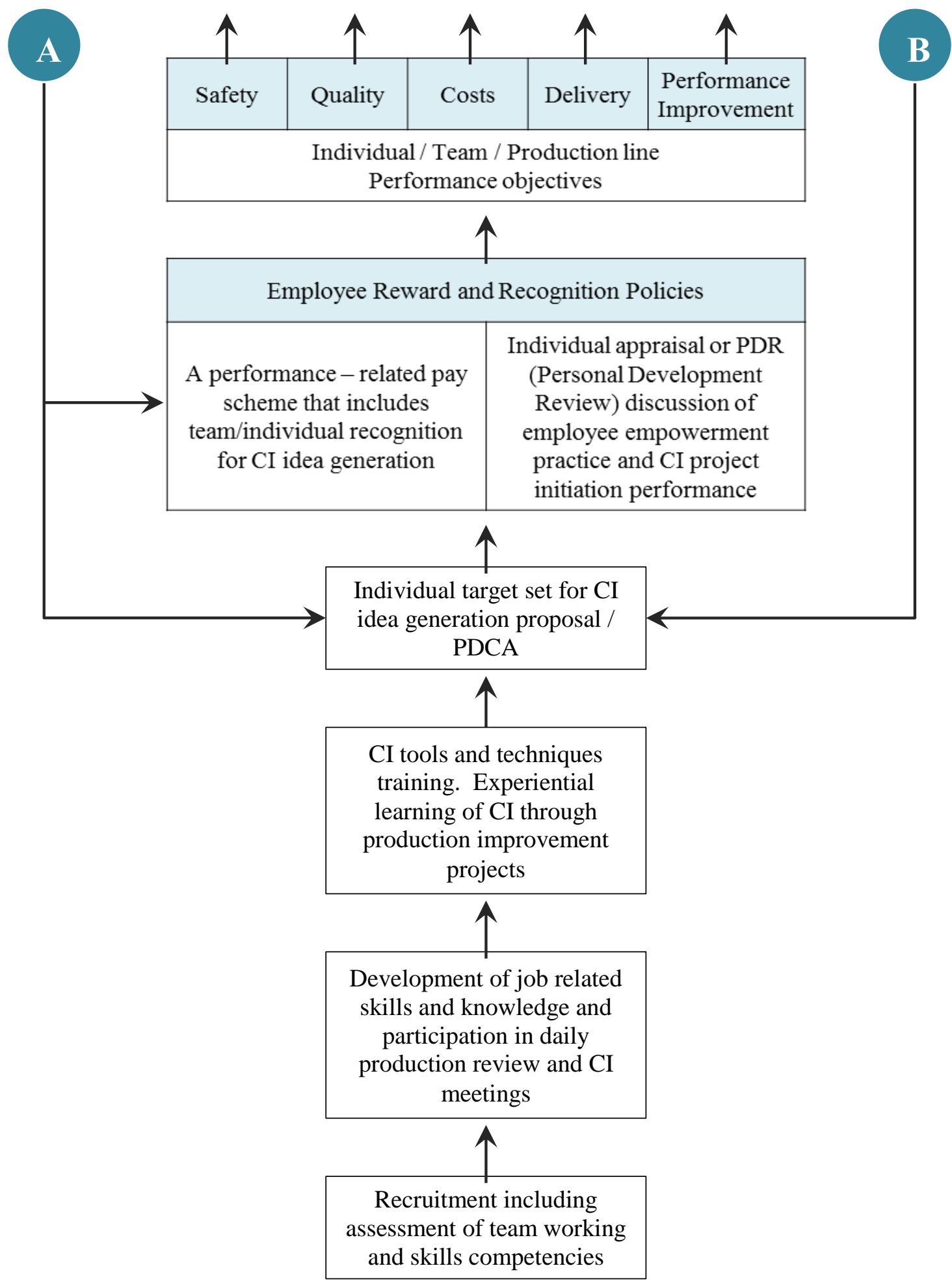




\section{Continuous Improvement Programme Management \\ Process Management}

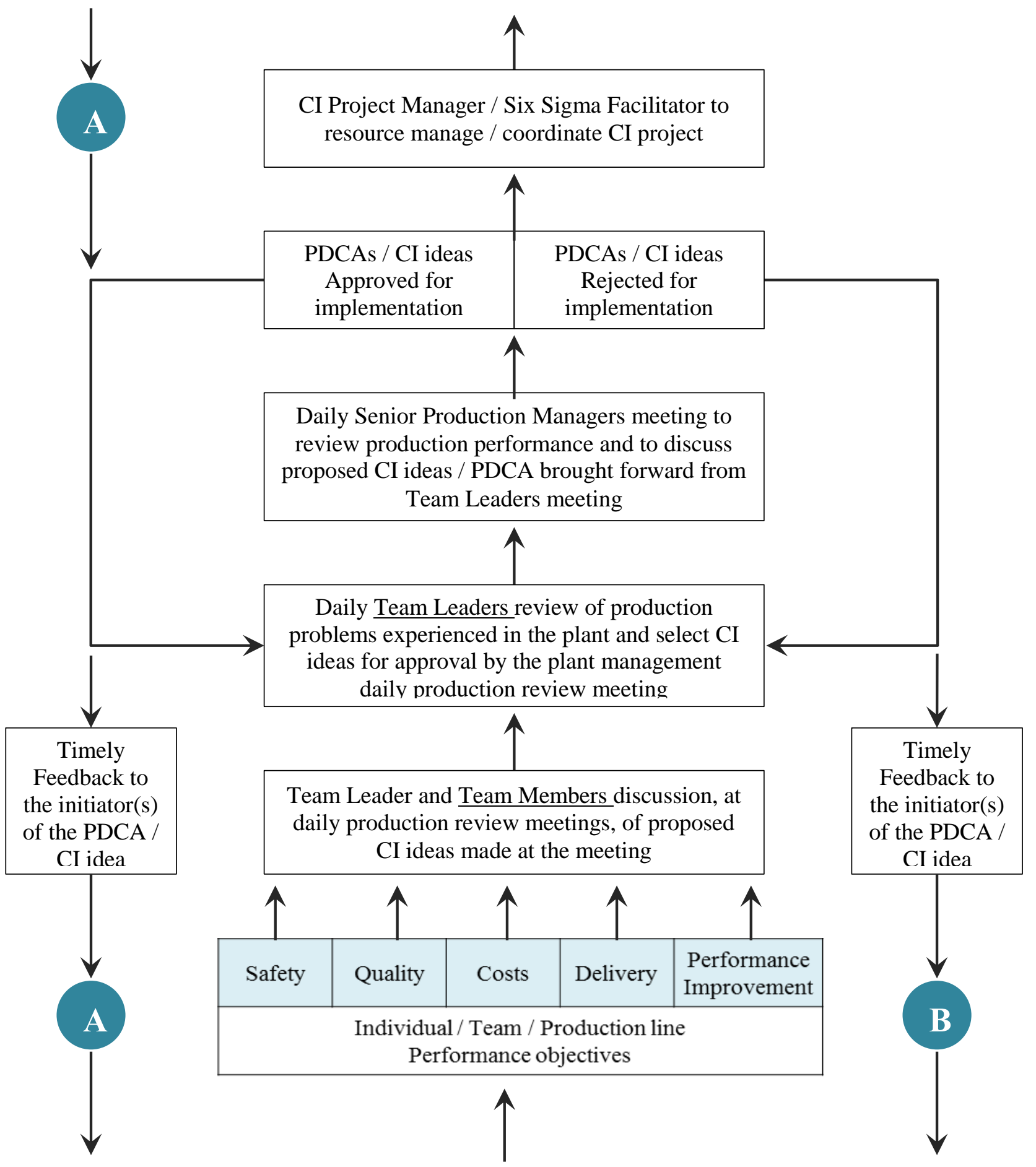




\section{Continuous Improvement Programme Management}

\section{The Business Purpose}

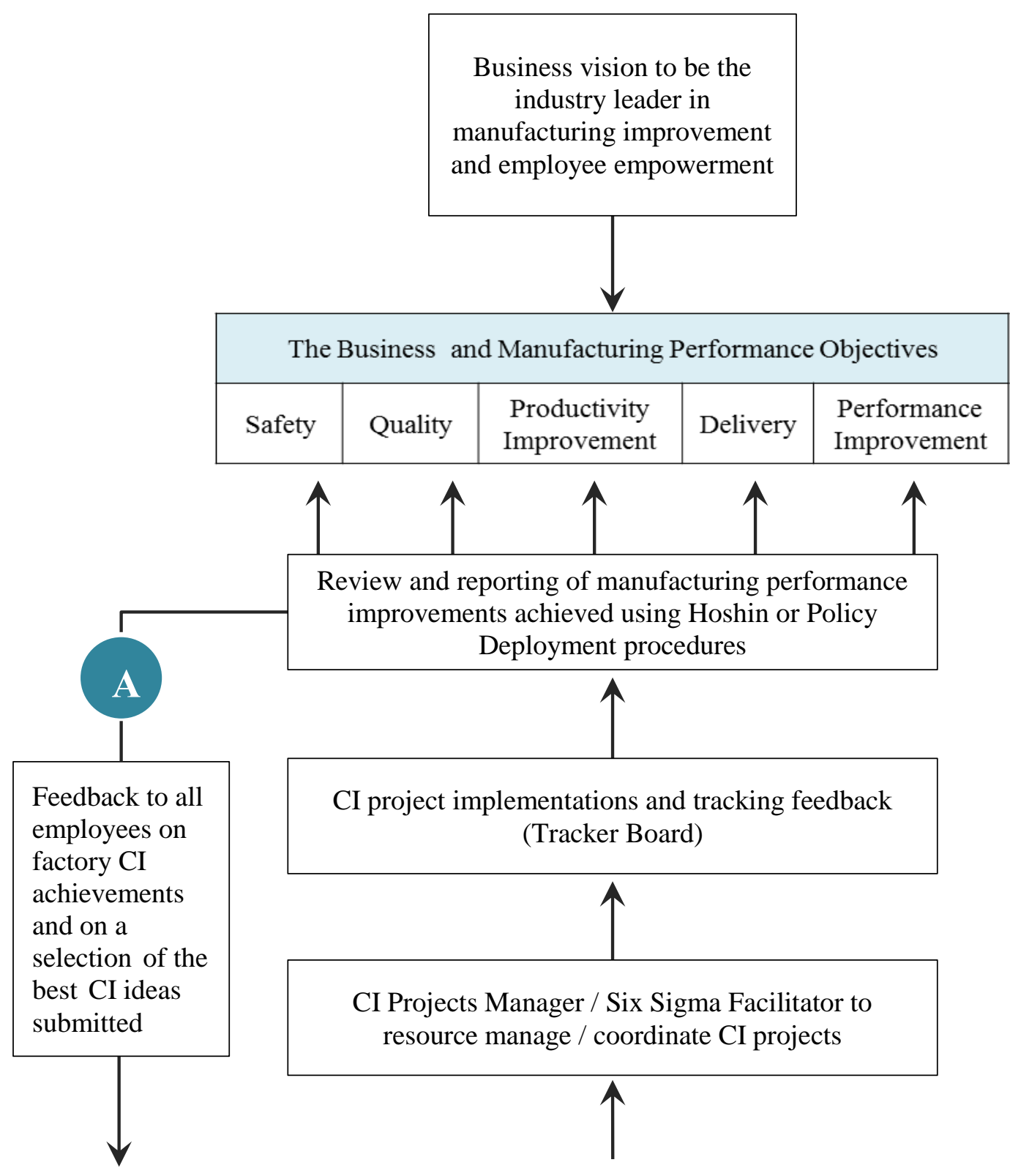

Appendix D. Financial Analysis for Investment in CI 
Assessing the opportunity cost of the allocation of 1 hour per week, for shop floor team meetings, to propose and discuss ideas for $\mathrm{CI}$ instead of producing at the scheduled rate through this period of time.

\section{For Plant 1}

Revenue of the business in December 2012 was $€ 212 \mathrm{~m}$

$€ 212 \mathrm{~m}$ equates to approximately (in December 2012)

$$
\frac{€ 212 \text { million }}{1.4 \text { euros to the } £}=£ 151 \mathrm{~m} \text { p.a. }
$$

Equating this turnover to sales revenue/hr. of production output (assuming that the opportunity cost of lost production/hr. is equivalent to sales income/hr.):

$$
\begin{array}{ll}
\frac{£ 151,000,000}{48 \text { working * }} & 120 \mathrm{hrs} / \quad=£ 26,215 \text { per hour } \\
\begin{array}{ll}
\text { weeks p.a. } & \text { week production }
\end{array} &
\end{array}
$$

thus for a 48 week working year the opportunity cost of scheduling a 1 hour Kaizen meeting per week

$$
=£ 26,215 * 48 \text { equates approximately to } £ 1,258,333 \text { of lost production output. }
$$

NB No time was allocated for CI idea generation during a production shift.

\section{For Plant 2}

Turnover of the business in 2012 was $£ 52 \mathrm{~m}$

Using the same assumption as above (about the opportunity cost of lost manufacturing output $/ \mathrm{hr}$. $=$ sales income/hr.):

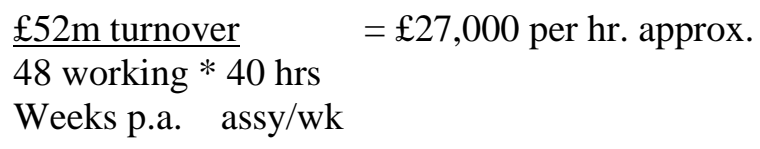

For a 48 week working year, the opportunity cost of scheduling a 1 hour Kaizen meeting per week $=£ 27,000 \times 48$ which equates approximately to $£ 1,300,000-\underline{\text { Actual }}=£ 1.5 \mathrm{~m}$ 


\section{Biographies}

\section{Dr. Michael JR Butler}

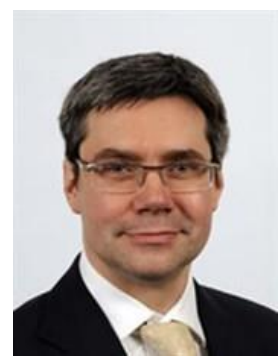

Michael JR Butler is Reader in Transformational Change, and Founder/Director of The TRANSFORMATION Project (www.thetransformationproject.co.uk), Aston Business School, U.K. His current research interest is understanding change from a multi-disciplinary perspective. He is on the Editorial Board of International Journal of Complex Governance Networks and Asia Pacific Journal of Business Administration. He has published in the British Journal of Management, Human Relations, International Journal of Operations and Production Management, Journal of Management, Leadership Quarterly and Organization Science. He has co-edited three books. His engaged scholarship (funded to $\mathrm{c} £ 1.5 \mathrm{~m}$ ) has been recognised (CMI and ESRC). The OECD used his research to evaluate international policy implementation.

\section{Professor Marek Szwejczewski}

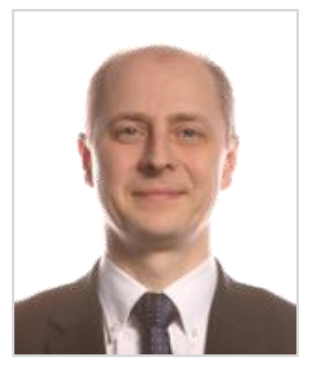

Marek is Professor of Operations Strategy and Director of the Best Factory Awards at Cranfield School of Management. His current research interests are manufacturing strategy, sustaining change initiatives, identifying customer hidden needs, supplier management, and new product portfolio management. Marek has received significant public and private funding for his research 
on factory performance in the UK and has co-authored several major reports. He has published extensively in both academic and journals including Production Planning and Control. Marek has recently published a book entitled Learning from World Class Manufacturers.

\section{Emeritus Professor Mike Sweeney}

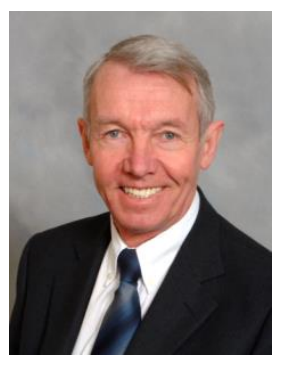

Mike is Emeritus Professor at Cranfield School of Management. He was previously the Director of the School of Defence Management at DCMT, Shrivenham from February 1995 to September 1997 and Director of the Innovation and Process Management Community, in the Cranfield School of Management, from January 2003 to September 2006. His research interests are the strategic management of manufacturing and service operations. He is the author of a number of articles and reports on industrial management subjects, and acts as a consultant to a number of international manufacturing and service companies. 